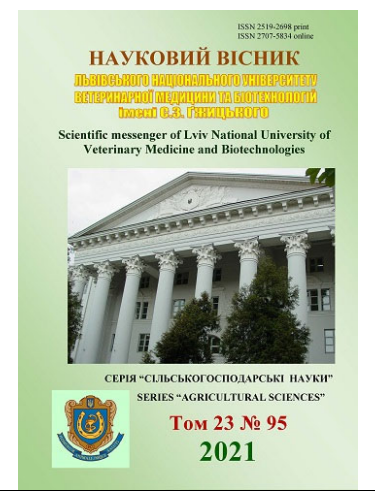

Науковий вісник Дьвівського національного університету ветеринарної медицини та біотехнологій імені С.3. Гжицького. Серія: Сільськогосподарські науки

\author{
Scientific Messenger of Lviv National University \\ of Veterinary Medicine and Biotechnologies. \\ Series: Agricultural sciences
}

\title{
Fish-water substantiation of the recirculation aqua system for the African clary catfish Clarias gariepinus (Burchell, 1822)
}

\author{
A. M. Trofymchuk ${ }^{1}$, N. Ye. Grynevych ${ }^{1}$, B. A. Romanchuk ${ }^{2}$, M. M. Svitelskyi ${ }^{3}$ \\ ${ }^{1}$ Bila Tserkva National Agrarian University, Bila Tserkva, Ukraine \\ ${ }^{2}$ Aqua System Organic Limited Liability Company (Aqua System Organic LLC), Vasylkiv, Ukraine \\ ${ }^{3}$ Polissia National University, Zhytomyr, Ukraine
}

\section{Article info}

Received 09.04.2021

Received in revised form 12.05 .2021

Accepted 13.05.2021

Bila Tserkva National Agrarian University, Pl. Soborna, $8 / 1$ Bila Tserkva, 09117, Ukraine. Tel.: +38-098-959-49-97 E-mail: gnatbc@ukr.net

Aqua System Organic Limited Liability Company (Aqua System Organic LLC), Kyivska Str., 97-A Vasylkiv, 08606, Ukraine.

Polissia National University, Stary Boulevard, 7, Zhytomyr, 10008, Ukraine.
Trofymchuk, A. M., Grynevych, N. Ye., Romanchuk, B. A., \& Svitelskyi, M. M. (2021). Fish-water substantiation of the recirculation aqua system for the African clary catfish Clarias gariepinus (Burchell, 1822). Scientific Messenger of Lviv National University of Veterinary Medicine and Biotechnologies. Series: Agricultural sciences, 23(95), 15-24. doi: 10.32718/nvlvet-a9502

The advantages of Clarias gariepinus over other valuable species of fish raised in closed water supply systems are rapid growth, the ability to obtain marketable products in 6 months, unpretentiousness to the conditions of detention, valuable taste: clary catfish meat contains polyunsaturated fatty acids ( omega-3) and meets the requirements of a balanced healthy diet. The study was conducted on one of the farms for growing clary catfish, which is part of the Union of Aqua Farmers of Ukraine LLC "Aquapromgroup" in the Odesa region. To optimize the work of the farm for growing commercial Claria catfish in ultrasound, the use of polycyclic (8-cyclic) method instead of 2-cyclic, which currently operates, will allow more efficient use of production capacity, technological equipment and sell 127,784 tons of fish, which is 2.4 times more. To implement the technology it is necessary to grow the following number of fish: at the 1st stage - 24000 specimens, at the 2nd stage - 20400 specimens, at the 3rd stage - 17748 specimens, at the 4th stage 15973 of each of 8 cycles. During the year the farm sells 127.784 copies. clary catfish with an average weight of $1 \mathrm{~kg}$. Farm costs for compound feed: for feed for fry ("Biomar") - 234432 UAH, for feed for other age groups of clary catfish - $2879860 \mathrm{UAH}$. The total cost of feed - 3114292 UAH. If all the requirements of the 8-cycle technological process of growing catfish in closed water supply installations (total volume of pools $-131 \mathrm{~m}^{3}$ ) the cost of $1 \mathrm{~kg}$ of fish will be 39 hryvnias, the farm will receive 3960300 hryvnias of gross profit from sales of marketable products, the profitability of production will be $79.5 \%$. Therefore, during the performance of this work, we proved the advantage of using the polycyclic method of growing clary catfish in closed water supply installations.

Key words: aquaculture, recirculation aqua system, Clarias gariepinus, technological process, profitability.

\section{Рибоводно-технологічне обгрунтування рециркуляційної аквасистеми для африканського кларієвого сома Clarias gariepinus (Burchell, 1822)}

\author{
А. М. Трофимчук ${ }^{1}$, Н. Є. Гриневич ${ }^{1}$, Б. А. Романчук ${ }^{2}$, М. М. Світельський ${ }^{3}$ \\ ${ }^{1}$ Білоцерківський наџіональний аграрний університет, м. Біла Церква, Україна \\ ${ }^{2}$ ТОВ “Аква Систем Органік”, м. Васильків, Україна \\ ${ }^{3}$ Поліський національний університет, м. Житомир, Украӥна
}

\footnotetext{
Перевагою Clarias gariepinus щзодо інших цінних видів риб, яких вирощують в установках замкнутого водопостачання, є насамперед: ивидкий темп росту, можливість отримати товарну продукцію за 6 місяців, невибагливість до умов утримання, иінні смакові якості: м'ясо кларієвого сома містить поліненасичені жирні кислоти (омега-3) і відповідає вимогам збалансованої здорової їжі. Дослідження проводилось на одній з ферм з вирощування кларієвого сома, яка входить до спілки аквафермерів України ООО “Аквапромгруп”, щзо в Одеській області. Для оптимізації роботи господарства з вирощування товарного кларієвого сома в
} 
УЗВ застосування полічиклічного (8-циклічного) методу замість 2-циклічного, який діє на теперішній час, дозволить раціональніше використовувати виробничі потужності, технологічне обладнання та реалізувати 127,784 тонни риби, шзо у 2,4 раза більше. Для реалізації технологї необхідно вирощувати таку кількість риби: на 1 етапі - 24000 екз., на 2 етапі - 20400 екз., на 3 етапі 17748 екз., на 4 етапі - 15973 кожного з 8 циклів. За рік господарство реалізує 127784 екз. кларієвого сома середньою масою 1 кг. Витрати господарства на комбікорма: на корм для мальків (“Біомар") - 234432 грн, на корм для інших вікових груп кларієвого сома - 2879860 грн. Загальні витрати на корм - 3114292 грн. За дотримання всіх вимог 8-циклічного технологічного процесу ви-

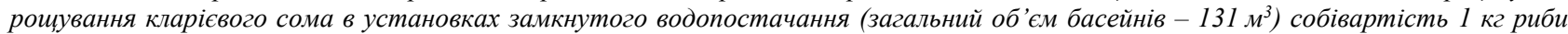
становитиме 39 гривень, господарство отримає 3960300 грн валового прибутку від реалізації товарної продукиії, рентабельність виробництва становитиме 79,5\%. Отже, під час виконання даної роботи нами було доведено перевагу використання поліииклічного методу вирощуванні кларієвого сома в установках замкнутого водопостачання.

Ключові слова: аквакультура, рециркуляційна аквасистема, Clarias gariepinus, технологічний процес, рентабельність.

\section{Вступ}

Аквакультура в установках замкнутого водопостачання (УЗВ) є технологією для вирощування риб або інших водних організмів 3 повторним використанням води для цілей виробництва. Дана технологія грунтується на застосуванні механічних і біологічних фільтрів i, по суті, може використовуватися для вирощування будь-яких об'єктів аквакультури, наприклад: риб, креветок, двостулкових молюсків і т. д. Проте рециркуляційні технології застосовуються головним чином в рибництві (Vlasov, 2012).

Рециркуляція швидко розвивається в багатьох ділянках рибного сектора, надаючи широкий вибір для всіх зацікавлених осіб. УЗВ використовуються в широкому спектрі виробничих господарств: від великих промислових підприємств, які виробляють значну кількість тонн риби на рік, до невеликих спеціалізованих систем, використовуваних для поповнення запасів або для порятунку зникаючих видів. Рециркуляція води може відбуватися з різною інтенсивністю, залежно від того, яка кількість води рециркулюється або використовується повторно. Деякі господарства являють собою інтенсивні рибоводні комплекси, розташовані в критих, ізольованих будівлях і використовують всього лише 200 літрів свіжої води на кілограм вирощеної риби, тимчасом як інші системи є традиційними господарствами під відкритим небом (Vlasov, 2013).

3 екологічної точки зору менша кількість використовуваної рецеркуляційної води, безперечно, є сприятливим фактором, оскільки в багатьох регіонах вода перетворилася в обмежений ресурс. Завдяки меншому споживанню води, видалення продуктів життєдіяльності риб також стає легшим, здешевленим, оскільки обсяг води, що скидається, набагато менший, ніж той, що скидається традиційними рибними господарствами. Тому аквакультура в УЗВ вважається екологічним способом отримання рибної продукції (Vlasov, 2012).

Традиційне рибництво повністю залежить від зовнішніх умов, таких як температура води у водоймі, чистота води, рівень кисню, наявність мікро - та макрофітів і т. д. У рециркуляційних аквасистемах зовнішні чинники відсутні повністю або частково, залежно від ступеня рециркуляції і конструкції установки. Рециркуляція дозволяє рибоводам контролювати всі виробничі параметри. Технологічні навички рибовода в управлінні УЗВ стають не менш важливими, ніж його вміння доглядати за рибою (Grynevych, 2016).

Контроль таких параметрів, як температура води, рівень кисню або навіть денне світло, забезпечує стабільні і оптимальні умови для риб, що своєю чергою призводить до меншого стресу і кращого росту. Результатом подібних стабільних умов стає постійний і передбачуваний ріст, що дозволяє рибоводам точно прогнозувати, коли риба досягне певного етапу розвитку або розміру (Prychepa et al., 2021; Hrynevych et al., 2021).

Найважливішою перевагою цього $\epsilon$ можливість складання точного виробничого плану і прогнозування точного часу, коли риба буде готова до реалізації. Це позитивно впливає на загальне управління господарством і поліпшує здатність рибоводів до конкурентоспроможної реалізації риби.

Використання рециркуляційних технологій в рибництві має ряд переваг. Однією з найважливіших $є$ та, що в УЗВ вплив патогенів значно знижено, оскільки потрапляння в установку збудників інвазійних захворювань 3 навколишнього середовища зведено до мінімуму внаслідок обмеженого використання води. У звичайних умовах вода для рибництва береться із відкритої водойми, що, природно, підвищує ризик внесення збудників захворювань.

В УЗВ, враховуючи обмежене споживання води, вода зазвичай береться зі свердловини, дренажної системи або джерела, де ризик інвазій мінімальний. Фактично в багатьох УЗВ зовсім немає проблем із захворюваннями, тому використання лікарських засобів значно знижено, що позитивно впливає як на виробництво, так і на навколишнє середовище.

Щоб видаляти відходи, які виділяються рибами, i додавати кисень для підтримки життєдіяльності риб, воду в УЗВ необхідно постійно очищати. УЗВ, по суті, є досить простою системою. Основний принцип рециркуляції полягає у водостоку рибоводних басейнів - вода надходить у механічний фільтр, звідти в біологічний фільтр, потім вона аерується, 3 неї видаляється вуглекислий газ, після чого вона знову подається в рибоводні басейни.

До системи можна додати ряд інших елементів, наприклад оксигенацію 3 використанням чистого кисню, дезінфекцію за допомогою ультрафіолетового випромінювання або озону, автоматичне регулювання рівня $\mathrm{pH}$, теплообмін, систему денітрифікації і т. д., залежно від конкретних потреб. 


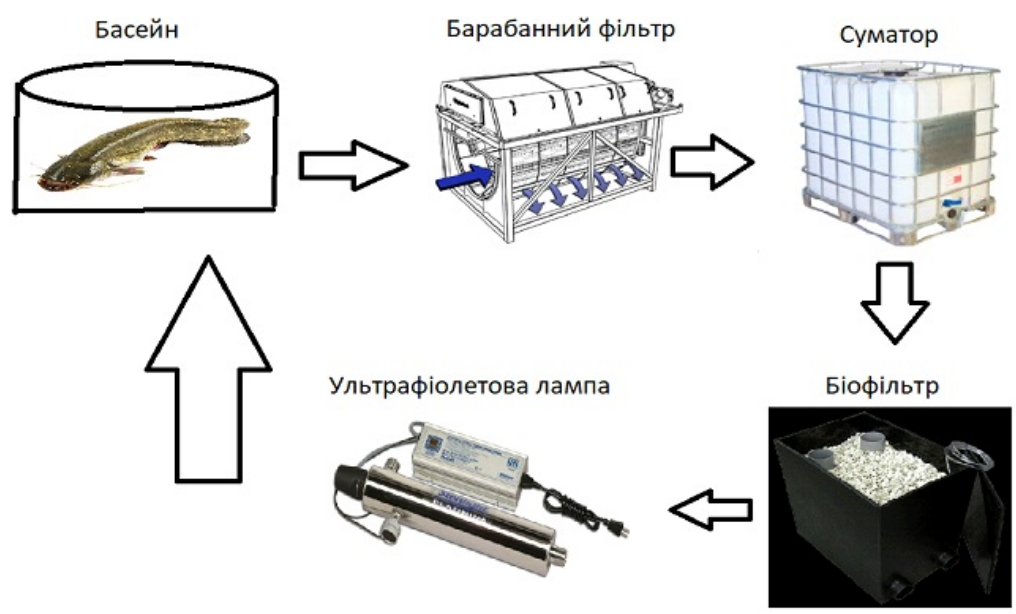

Рис. 1. Схема УЗВ для вирощування кларієвого сома

Годівля гідробіонтів в рециркуляційних системах відбувається в основному екструдованими кормами. Кисень $\left(\mathrm{O}_{2}\right)$ надходить через зябра і необхідний для виробництва енергії і розщеплення білків, тимчасом як вуглекислий газ $\left(\mathrm{CO}_{2}\right)$ i аміак $\left(\mathrm{NH}_{3}\right)$ утворюються як відходи.

Неперетравлений корм виділяється у воду у вигляді екскрементів: органічна речовина (OP), а також завислі речовини (3В). Вуглекислий газ і аміак виділяються в воду через зябра. Отже, риби споживають кисень і корми, в результаті чого вода в системі забруднюється екскрементами, вуглекислим газом i аміаком. В УЗВ рекомендується використовувати тільки сухі корми.

Необхідно уникати застосування як корму малоцінної риби в будь-якій формі, оскільки вона сильно забруднює систему і значно підвищує ймовірність потрапляння збудників різних захворювань.

Використання сухих збалансованих кормів є безпечним, перевага також полягає в тому, що їх склад точно відповідає біологічним потребам риб. Сухий корм вноситься у формі гранул різного розміру, придатних для будь-якого віку риб, а інгредієнти сухих кормів можуть комбінуватися по-різному, що дозволяє розробляти спеціалізовані корми: стартові, продукційні, для ремонтно-маточного стада і т. д.

У професійно збалансованій системі корми, які згодовуються, практично повністю поїдаються вирощуваними гідробіонтами, це зводить до мінімуму кількість відходів, що своєю чергою знижує навантаження на водоочисні пристрої. Кормовий коефіцієнт (КК) поліпшується, і рибовод отримує більший вихід продукції та менше навантаження на систему фільтрації. Не спожитий корм означає зайву витрату грошей і $є$ додатковим навантаженням на систему фільтрації води.

Варто зазначити, що існують корми, особливо підходящі для використання в УЗВ. Склад подібних кормів сприяє максимальному засвоєнню протеїнів i відповідно зведення до мінімуму виділення аміаку у воду (Hrynevych et al., 2019).

Правильний вибір конструкції басейнів, тобто розміру і форми, глибини води, здатності до самоочищення і т. д. має значний вплив на ефективність ви- рощування об’єктів рибництва. Якщо риби ведуть донний спосіб життя, найбільш важливою $є$ площа поверхні, а глибина води і швидкість течії можуть бути знижені, тимчасом як для пелагічних видів, наприклад лососевих, більший обсяг води є сприятливим і ефективність їх вирощування зростає за більшої швидкості течії води.

У круглому басейні або квадратному басейні зі зрізаними кутами внаслідок гідравлічних закономірностей і гравітаційних сил час перебування органічних часточок $є$ порівняно коротким, практично декілька хвилин, і залежить від розміру басейну. Весь водяний стовп в басейні обертається навколо центру. Вертикальний водозабір з установкою для горизонтального регулювання $є$ ефективним засобом для контролю течії в подібних басейнах. У прямокутному басейні не можуть бути створені гравітаційні сили для забезпечення течії, а гідравліка не має позитивного ефекту на видалення часточок. 3 іншого боку, якщо басейн ефективно зарибнений, здатність басейну даного типу до самоочищення залежить більшою мірою від активності риб, ніж від конструкції басейну. У всіх типах басейнів ухил дна не впливає на здатність до самоочищення, але при спуску басейну він допомагає повністю спустити воду. Порівняно з прямокутними - круглі басейни займають багато місця, що підвищує вартість будівлі. Зрізавши кути квадратного басейну ми отримаємо восьмикутну форму, яка оптимальніше використовує простір, ніж круглі басейни, але одночасно забезпечує ті ж позитивні гідравлічні ефекти. Важливо зазначити, що при будівництві великих басейнів перевага завжди віддається круглій формі, оскільки вона є найбільш міцною конструкцією, а також найдешевшим способом споруди ємностей для риби (Juin et al., 2017).

Тип басейнів, що займає проміжне місце між круглими і прямокутними, так званий овальний басейн, також поєднує здатність до самоочищення круглих басейнів і ефективне використання простору, типове для прямокутних басейнів. Однак на практиці цей тип басейнів використовується рідко, ймовірно тому, що його установка вимагає додаткової роботи. 
Контроль і регуляція рівнів кисню в круглих басейнах або інших подібних конструкціях здійснюються порівняно просто, оскільки водяний стовп постійно перемішується, внаслідок чого вміст кисню є практично однаковим в усьому басейні. Це означає, що дуже легко, залежно від ситуації, підвищити або знизити рівень кисню в басейні.

3 іншого боку, в прямокутних басейнах вміст кисню завжди вищий біля водозабору і нижчий біля водостоку, що забезпечує різні умови, в залежності від того, де перебуває риба. Оксиметр для вимірювання вмісту кисню у воді завжди повинен розміщуватися в зоні з найбільш низьким вмістом кисню, яка в прямокутних басейнах розташована неподалік водостоку. Цей градієнт ускладнює регуляцію вмісту кисню, оскільки час між підвищенням або пониженням рівня кисню біля водозабору і біля водостоку може становити до однієї години. Дана ситуація може призвести до постійного підвищення і зниження концентрації кисню замість невеликих коливань навколо заданого рівня (Juin et al., 2017).

Водостоки басейнів повинні бути сконструйовані так, щоб вони забезпечували оптимальне видалення часточок відходів, мають бути грати 3 відповідним розміром отворів. Видалення загиблих риб під час щоденного обслуговування також має бути простим. Басейни можуть бути забезпечені сигналізацією зниження рівня води.

Як показує досвід, механічна фільтрація води, яка витікає 3 рибоводних басейнів, є оптимальним методом видалення завислих органічних відходів. Сьогодні майже всі господарства, що використовують УЗВ, фільтрують воду, що витікає із басейнів, за допомогою так званого "Мікросита" у барабанному фільтрі, обладнаного фільтрувальною тканиною 3 розміром вічок 40-100 мікрон. Його конструкція забезпечує м'яке видалення завислих частинок (Juin et al., 2017).

Функціонування барабанного фільтра.

1. Вода надходить у барабан.

2. Вода профільтровується через фільтрувальні елементи барабана. Рушійною силою фільтрації $є$ різниця рівнів води всередині і ззовні барабана.

3. Тверді частинки затримуються на фільтрувальних елементах і піднімаються до зони зворотної промивки внаслідок обертання фільтра.

4. Вода розпорошується 3 промивних форсунок, розташованих із зовнішнього боку фільтрувальних елементів. Органічна речовина вимивається 3 фільтрувальних елементів на шламовий піддон.

5. Шлам самопливом витікає разом із водою з фільтра і видаляється 3 рибного господарства для зовнішньої очистки стічної води.

Фільтрація 3 використанням мікросита має такі переваги:

- зниження органічного навантаження на біофільтр;

- підвищення прозорості води внаслідок видалення з неї органічних часточок;

- покращення умов нітрифікації, оскільки біофільтр не забивається;

- стабілізуючий вплив на процеси біофільтрації.

Механічний фільтр не видаляє всі органічні речовини, найдрібніші часточки проходять крізь нього так само, як і розчинені речовини, такі як сполуки азоту або фосфору. Фосфат $є$ інертною речовиною без токсичних ефектів, але азот у формі вільного аміаку $\left(\mathrm{NH}_{3}\right)$ токсичний і має бути перетворений в біофільтрі в нешкідливий нітрат. Розкладання органічної речовини і аміаку є біологічним процесом, що здійснюється бактеріями в біофільтрі. Гетеротрофні бактерії окислюють органічну речовину, споживаючи кисень i виробляючи вуглекислий газ, аміак і шлам. Нітрифікуючі бактерії перетворюють аміак в нітрит, а потім в нітрат (Hrynevych et al., 2019).

Ефективність біофільтрації залежить, головним чином, від таких факторів:

- температури води в системі

- рівня рН в системі.

Для досягнення прийнятної швидкості нітрифікації температура води повинна бути в межах $10-35{ }^{\circ} \mathrm{C}$ (оптимально близько $30{ }^{\circ} \mathrm{C}$ ), а рівень $\mathrm{pH}-$ між 7 і 8 . Температура води найчастіше залежить від виду риби, що вирощують, і відповідно встановлюється не так, щоб забезпечити найбільш оптимальну швидкість нітрифікації, а на створення оптимальних умов для вирощування гідробіонта. Проте важливо регулювати $\mathrm{pH}$, оскільки малі рівні $\mathrm{pH}$ знижують ефективність біофільтрації. Таким чином, для досягнення високої швидкості бактеріальної нітрифікації $\mathrm{pH}$ повинен утримуватися вище ніж 7,0. 3 іншого боку, більш високий $\mathrm{pH}$ призводить до постійно зростаючої кількості вільного аміаку $\left(\mathrm{NH}_{3}\right)$, що збільшує токсичний ефект. Отже, необхідно знайти рівновагу між цими двома протилежними процесами регулюванням $\mathrm{pH}$. Рекомендована точка - між рН 7,0 і рН 7,5.

Значення $\mathrm{pH}$ у водоочисній системі визначається такими основними факторами:

- вуглекислий газ $\left(\mathrm{CO}_{2}\right)$, вироблений рибами і за рахунок біологічної активності в біофільтрі.

- кислота, вироблена в процесі нітрифікації.

$\mathrm{CO}_{2}$ видаляється за допомогою аерації води, причому на даному етапі також відбувається дегазація.

В процесі нітрифікації утворюється кислота $\left(\mathrm{H}^{+}\right)$, що знижує рівень $\mathrm{pH}$. Стабілізація $\mathrm{pH}$ вимагає додавання будь-якого лугу. 3 цією метою до води додається вапно, гідроксид натрію.

У біофільтрах зазвичай використовується пластмасовий наповнювач з великою площею поверхні на одиницю об'єму біофільтра. Бактерії ростуть на наповнювачі, утворюючи тонку плівку i, таким чином, займають дуже велику площу. У добре спроектованому біофільтрі площа поверхні на одиницю об'єму повинна бути якомога більшою, проте біофільтр не повинен бути наповнений занадто щільно, щоб не забитися органічною речовиною в процесі експлуатації. Тому важливо мати значний відсоток вільного простору, через який може протікати вода та можливість здійснення процедури зворотного промивання. Подібні процедури зворотного промивання повинні застосовуватися через відповідні проміжки часу, раз на тиждень або місяць, залежно від навантаження на фільтр.

Стисле повітря використовується для створення в фільтрі турбулентності, відриває органічний матеріал від наповнювача. Під час промивання вода відключа- 
ється від біофільтра. Брудна вода зливається і видаляється перед його повторним підключенням до системи (Juin et al., 2017).

Біофільтри УЗВ можуть бути спроектовані як фільтри з плаваючим або нерухомим завантаженням. Усі біофільтри, які використовуються сьогодні в рециркуляції, при експлуатації повністю занурені у воду. У фільтрах з нерухомим завантаженням пластмасовий заповнювач закріплений і не рухається. Вода протікає через нього ламінарним потоком і стикається 3 бактеріальної плівкою. У фільтрах 3 плаваючим завантаженням пластмасовий заповнювач рухається у воді, що міститься всередині біофільтра, за рахунок течії, створеної нагнітанням всередину повітря. Через постійний рух наповнювача фільтри 3 плаваючим завантаженням можуть бути наповнені щільніше, ніж фільтри 3 нерухомим завантаженням, завдяки чому досягається вища швидкість обороту води на одиницю об'єму біофільтра. Однак швидкість обороту води на одиницю площі фільтра не має особливого значення, бо ефективність бактеріальної плівки в двох типах фільтрів практично однакова.

3 іншого боку, фільтри 3 нерухомим завантаженням видаляють також дрібні органічні частки, оскільки ті прилипають до бактеріальної плівки. Тому фільтри 3 нерухомим завантаженням також функціонують як блоки для тонкої механічної фільтрації, що видаляють органічний матеріал мікроскопічного розміру i очищають воду дуже ефективно. У фільтрах з плаваючим завантаженням неможливо досягти подібного ефекту, оскільки постійна турбуленція води не дозволяє частинкам затримуватися на поверхні. У будь-якій системі можуть використовуватися обидві системи фільтрації. Вони також можуть комбінуватися, використовуючи плаваюче завантаження для економії місця, а нерухоме - для використання ефекту затримування часточок на поверхні.

Існують різні рішення кінцевої конструкції систем біофільтрації, залежно від розміру господарства, об’єктів рибництва, розміру риб і т. д. (Oké \& Goosen, 2019).

Після проходження системи механічного очищення вода потрапляє в ємність, де відбувається ііі підігрів до необхідної температури. Також в цій ємності містяться датчики рівня води, які безпосередньо відповідають за контроль рівня води в певному модулі. При спрацьовуванні цього датчика, вмикається насос, який закачує воду далі по системі в біофільтр і вимикається, коли спрацьовує нижній датчик суматора.

УФ-дезінфекція заснована на застосуванні світла 3 такою довжиною хвиль, яка руйнує ДНК в біологічних організмах. В аквакультурі вона спрямована проти патогенних бактерій і одноклітинних організмів. Даний метод обробки використовується в медичних цілях протягом десятиліть і не впливає на риб, оскільки УФ-обробка води відбувається поза рибоводною зоною. Важливо розуміти, що бактерії так швидко ростуть на органічній речовині, що контроль їх чисельності в традиційних рибних господарствах має обмежені ефекти. Найкращий контроль досягається, коли ефективна механічна фільтрація комбінується 3 ретельною біологічною фільтрацією, що дозволяє ефективно видаляти органіку з відпрацьованої води і УФ-випромінювання працює ефективніше (Oké \& Goosen, 2019).

Доза УФ може бути виражена в різних одиницях. Однією з найбільш широко використовуваних є вимір

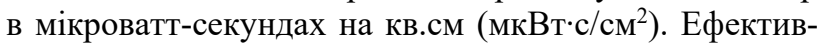
ність залежить від розмірів i видів організмів, які потрібно знищити, а також від каламутності води. Для контролю бактерій і вірусів вода повинна бути оброблена приблизно 2000-10000 мкВт·с/см², щоб знищити 90 \% організмів; для грибів буде потрібно - 10000100000 мкВт·с $/ \mathrm{cm}^{2}$, а для мікроскопічних паразитів -

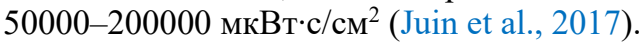

Для максимальної ефективності УФ-освітлення, яке використовується в аквакультурі, має функціонувати під водою; лампи, укріплені над водою, через відзеркалення з поверхні води будуть мати незначний ефект або взагалі не мати його.

У зв'язку з цим, метою була оптимізація технології вирощування кларієвого сома в установках замкнутого водопостачання (УЗВ) фермерського господарства, яке входить до спілки аквафермерів України ООО “Аквапромгруп”, що в Одеській області.

\section{Матеріал і методи досліджень}

Дослідження проводилось на одній з ферм 3 вирощування кларієвого сома, яка входить до спілки аквафермерів України ООО “Аквапромгруп”, що в в Одеській області. Господарство неповносистемне.

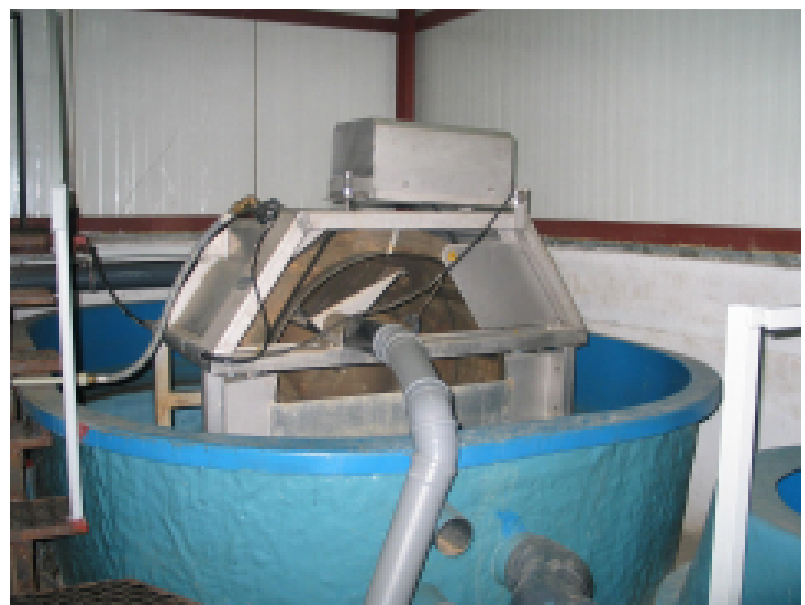

Рис. 2. Механічний фільтр ООО “Аквапромгруп”

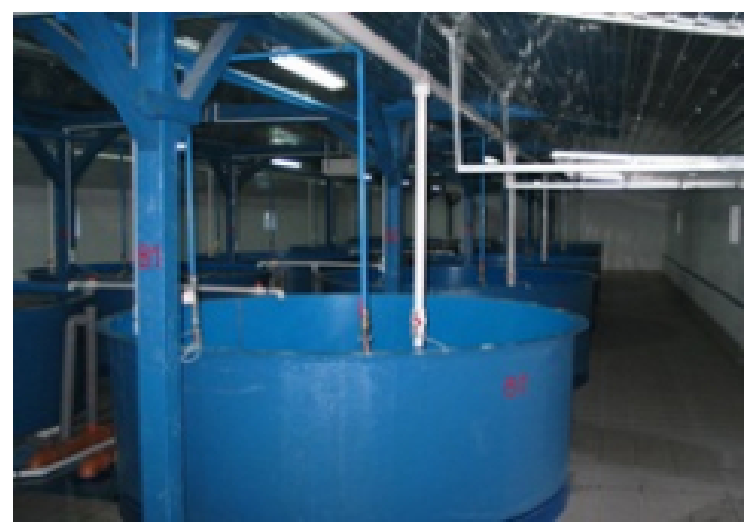

Рис. 3. Басейновий комплекс ООО “Аквапромгруп” 


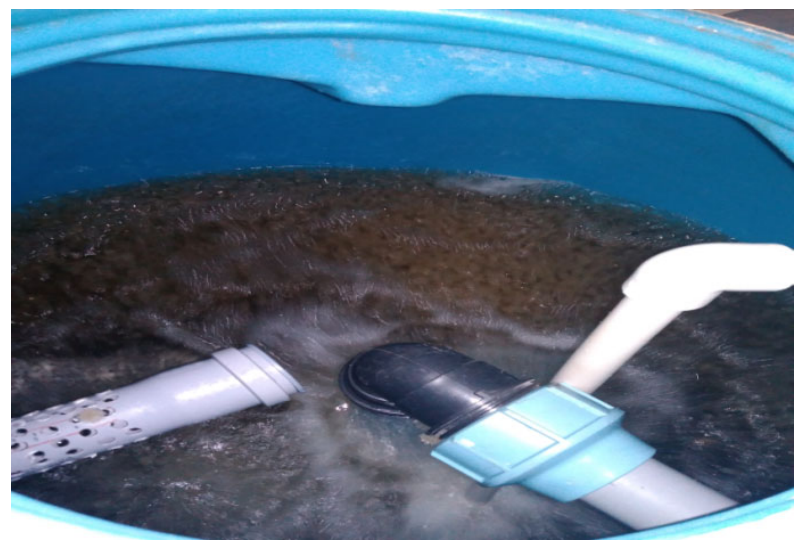

Рис. 4. Біологічний фільтр “Аквапромгруп”

Малька закупляють. Процес вирощування товарного кларієвого сома відбувається за рибоводнобіологічними показниками, наведеними у табл. 1.

\section{Таблиця 1}

Рибоводно-біологічні показники вирощування кларієвого сома в установках замкнутого водопостачання

\begin{tabular}{|c|c|}
\hline Показники & $\begin{array}{c}\text { Нормативне } \\
\text { значення }\end{array}$ \\
\hline $\begin{array}{l}\text { Початкова маса малька, якого завозять на } \\
\text { вирощування }\end{array}$ & 1,5 г \\
\hline Маса малька на першому етапі & 20 г \\
\hline Маса кларієвого сома на другому етапі & 100 г \\
\hline $\begin{array}{l}\text { Маса кларієвого сома на третьому етапі } \\
\text { вирощування }\end{array}$ & 300 г \\
\hline $\begin{array}{l}\text { Маса товарного кларієвого сома (четвертий } \\
\text { етап) }\end{array}$ & 1000 г \\
\hline Виживання на першому етапі вирощування & $80 \%$ \\
\hline Виживання на другому етапі вирощування & $85 \%$ \\
\hline Виживання на третьому етапі вирощування & $87 \%$ \\
\hline $\begin{array}{l}\text { Виживання на четвертому етапі вирощу- } \\
\text { вання }\end{array}$ & $90 \%$ \\
\hline $\begin{array}{l}\text { Щільність посадки на першому етапі виро- } \\
\text { щування }\end{array}$ & $45 \kappa \Gamma / \mathrm{M}^{3}$ \\
\hline $\begin{array}{l}\text { Щільність посадки на другому етапі виро- } \\
\text { щування }\end{array}$ & $150 \kappa \Gamma / \mathrm{M}^{3}$ \\
\hline $\begin{array}{l}\text { Щільність посадки на третьому етапі ви- } \\
\text { рощування }\end{array}$ & $200 \kappa \Gamma / \mathrm{M}^{3}$ \\
\hline $\begin{array}{l}\text { Щільність посадки на четвертому етапі } \\
\text { вирощування }\end{array}$ & $200 \kappa \Gamma / \mathrm{M}^{3}$ \\
\hline $\begin{array}{l}\text { Кормовий коефіцієнт на першому етапі } \\
\text { вирощування мальків (корм “Біомар”) }\end{array}$ & 1,1 \\
\hline $\begin{array}{l}\text { Кормовий коефіцієнт на другому, третьому, } \\
\text { четвертому етапах вирощування (корм для } \\
\text { годівлі сомових ) }\end{array}$ & 1,0 \\
\hline Загальний робочий об’єм ємкостей & $131 \mathrm{~m}^{3}$ \\
\hline $\begin{array}{l}\text { Характеристика біофільтра (біозаванта- } \\
\text { ження) }\end{array}$ & $1000 \mathrm{~m}^{2} / \mathrm{M}^{3}$ \\
\hline Час повної заміни води у басейнах & 2 год \\
\hline Температура води у ємкостях & $27-30^{\circ} \mathrm{C}$ \\
\hline Вміст нітратів & 2 мг/л \\
\hline Рівень кисню & $2-6 \mathrm{мг/л}$ \\
\hline $\mathrm{pH}$ & $7,0-7,5$ \\
\hline
\end{tabular}

Господарство практикує вирощування кларієвого сома за двома циклами на рік по 6 місяців кожний.
Планова потужність господарства 52,40 тонни товарного сома за рік, середньою масою 1 кг.

Для розрахунків кількісних показників використали процесор MS Excel.

Кількість корму, яка необхідна для годівлі кларієвого сома на різних етапах вирощування, розрахували за формулою:

$$
\mathrm{K}=\mathrm{n} \times \mathrm{k} \times\left(\mathrm{m}_{\text {кін. }}-\mathrm{m}_{\text {поч. }}\right)
$$

де $\mathrm{K}$ - загальна кількість корму, витраченого на окремому етапі вирощування, кг; $\mathrm{n}$ - кількість риби (в кінці етапу вирощування), $\mathrm{k}$ - кормовий коефіцієнт

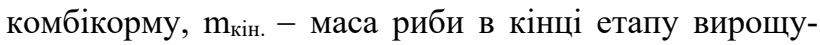
вання, $\mathrm{m}_{\text {поч }}-$ маса риби на початку цього етапу вирощування.

Розрахунки економічної ефективності результатів роботи рибницького господарства проводили із залученням основних економічних показників діяльності підприємства та 3 урахуванням кількості виробленої продукції.

Валовий прибуток від реалізації товарної продукції $\left(\Pi_{n}\right)$ розрахували за формулою:

$$
\Pi_{n}=B_{n}-C_{n}
$$

де $B_{n}$ - вартість реалізованої товарної продукції, грн.; $\mathrm{C}_{n}$ - собівартість реалізованої продукції (загальні витрати на вирощування товарної риби), грн.

Рентабельність виробництва товарної продукції $\left(P_{n}\right)$ розрахували за формулою:

$$
P_{n}=\frac{\Pi_{n}}{C_{n}} \times 100 \%,
$$

де $\Pi_{n}-$ валовий прибуток від реалізації товарної продукції, грн; $\mathrm{C}_{n}$ - собівартість реалізованої продукції, грн.

\section{Результати та їх обговорення}

За весь період дослідження гідрохімічних показників води в УЗВ відхилень від встановленої технологічної норми виявлено не було. Якість води відповідала оптимальним показникам для культивування кларієвого сома. Температурний режим підтримувався на рівні $28^{\circ} \mathrm{C}$. Значення водневого показника відповідали нормативним. Кисневий режим підтримувався в межах 4-5 мг/л, що відповідало оптимальним показникам для даного виду. Вміст нітритів та амонію також не перевищував оптимальних значень і був на рівні $0,15 \pm 0,05$ і 0,52 $\pm 0,02$ мг/л відповідно.

Для вирощування товарного кларієвого сома господарство використовує басейни ємністю: 2 басейна по $1,5 \mathrm{~m}^{3} ; 3$ басейна по $3 \mathrm{~m}^{3} ; 17$ басейнів по $7 \mathrm{~m}^{3}$ загальним робочим об'ємом $131 \mathrm{~m}^{3}$.

За 6 місяців отримує 26200 кг товарного кларієвого сома середньою масою 1 кг. За рік у господарстві відповідно одержують 52400 кг риби на реалізацію. Тобто практикують 2 цикла виробництва (рис. 5).

Для оптимізації роботи господарства пропонується запровадження поліциклічного способу вирощування кларієвого сома в установках замкнутого водопостачання (рис. $1,2,3)$. 


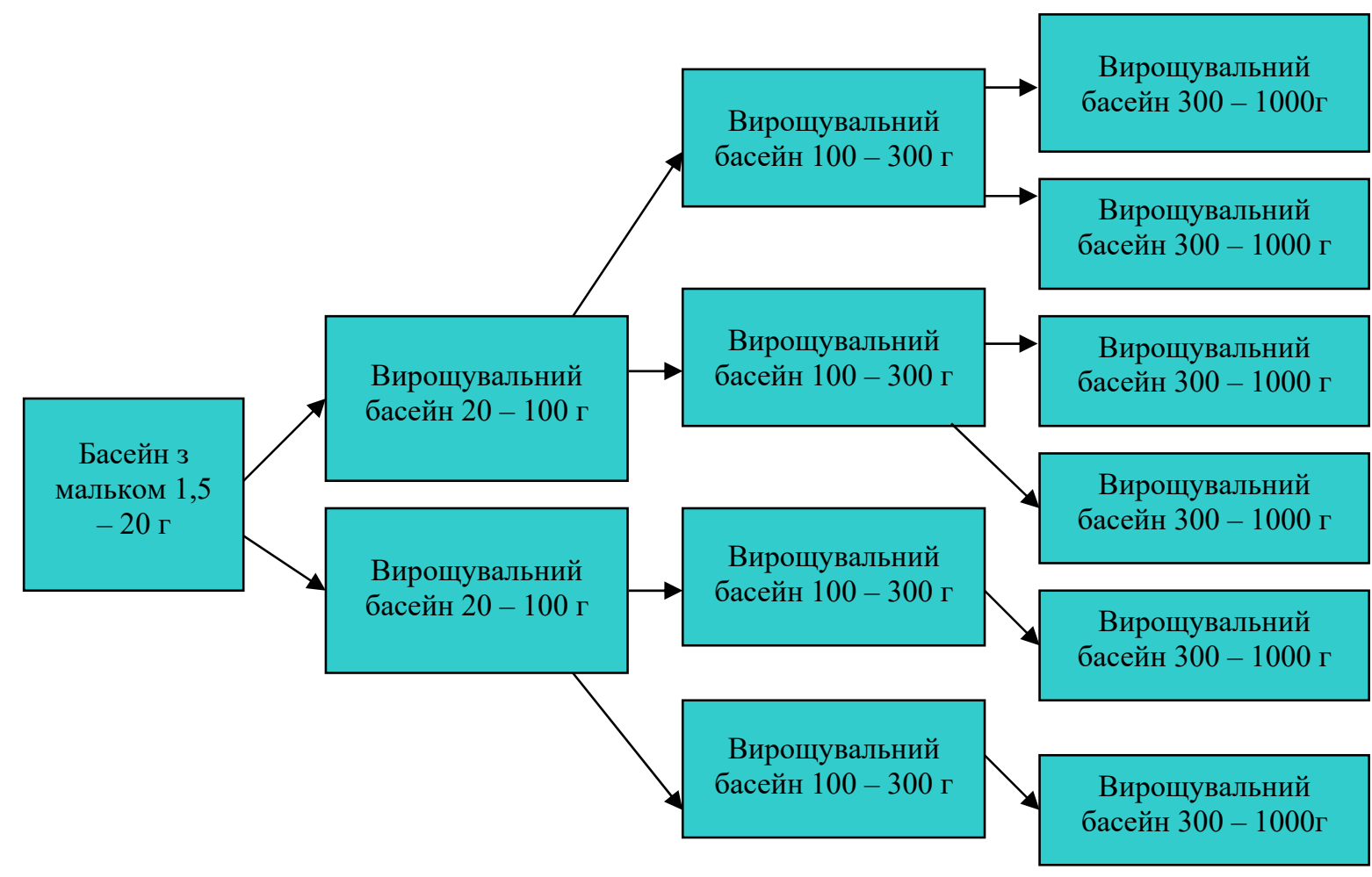

Рис. 5. Схема етапів поліциклічного виробництва

Пропонується така схема розподілу наявних у господарстві ємностей:

- $1,5 \mathrm{~m}^{3} \times 1+3 \mathrm{M}^{3} \times 3=10,5 \mathrm{~m}^{3}$ для першого етапу вирощування малька від 1,5 г до 20 г;

- $7 \mathrm{~m}^{3} \times 2=14 \mathrm{~m}^{3}$ для другого етапу вирощування риби від 20 г до 100 г;

- $7 \mathrm{~m}^{3} \times 4=28 \mathrm{~m}^{3}$ для третього етапу вирощування риби від 100 г до 300 г;

\section{Таблиця 2}

Розрахункові формули MS Excel
- $1,5 \mathrm{M}^{3} \times 1+7 \mathrm{M}^{3} \times 11=78,5 \mathrm{~m}^{3}$ для четвертого етапу вирощування риби від 300 г до 1000 г.

Розрахунок кількісті кларієвого сома на різних етапах вирощування на основі наведених розрахункових формул наведено в табл. 2. Для розрахунків кількісних показників використали процесор MS Excel.

\begin{tabular}{|c|c|c|c|c|c|c|c|c|}
\hline & $\mathrm{B}$ & $\mathrm{C}$ & $\mathrm{D}$ & $\mathrm{E}$ & $\mathrm{F}$ & $\mathrm{G}$ & $\mathrm{H}$ & I \\
\hline 2 & Обєм басейну & $=\mathrm{E} 5 * \mathrm{E} 6 /(1000 * \mathrm{C} 1)$ & & $=\mathrm{G} 5 * \mathrm{G} 6 /(1000 * \mathrm{E} 1)$ & & $=\mathrm{I} 5 * \mathrm{I} 6 /(1000 * \mathrm{G} 1)$ & & $=\mathrm{I} 5 * \mathrm{~K} 6 /(1000 * \mathrm{I} 1)$ \\
\hline 3 & & & & & & & & \\
\hline 4 & & & & & & & & \\
\hline 5 & Кількість (екз) & 45000 & & $=\mathrm{C} 5 * 0,8$ & & $=0,85 * \mathrm{E} 5$ & & $=0,87 * \mathrm{G} 5$ \\
\hline 6 & Вага (г) & 1,5 & & 20 & & 100 & & 300 \\
\hline 7 & $\begin{array}{l}\text { Потреба у кормах } \\
\text { (г) }\end{array}$ & $=\mathrm{E} 5 * 1,1 *(\mathrm{E} 6-\mathrm{C} 6)$ & & $=\mathrm{G} 5 * 1 *(\mathrm{G} 6-\mathrm{E} 6)$ & & $=\mathrm{I} 5 * 1 *(\mathrm{I} 6-\mathrm{G} 6)$ & & $=\mathrm{K} 5 * 1 *(\mathrm{~K} 6-\mathrm{I} 6)$ \\
\hline 8 & Варт 1кг/грн & 60 & & 22 & & 22 & & 22 \\
\hline 9 & Варт корму & $=\mathrm{C} 8 * \mathrm{C} 7 / 1000$ & & $=\mathrm{E} 8 * \mathrm{E} 7 / 1000$ & & $=\mathrm{G} 8 * \mathrm{G} 7 / 1000$ & & $=\mathrm{I} 8 * \mathrm{I} 7 / 1000$ \\
\hline
\end{tabular}

За вищенаведеними розрахунками отримуємо кількість кларієвого сома на різних етапах вирощування з урахуванням відсотку виживання (табл. 1).

Результати розрахунків узагальнимо у табл. 3 .
Виходячи 3 тривалості кожного етапу вирощування 1,5 місяця, планується потужність господарства 15973 тонн на 8 циклів (12 міс. / 1,5 міс.), тобто $15973 \times 8=127784$ тонни товарного сома за рік (середньою масою 1 кг). 
Таблиця 3

Кількість риби на початку різних етапів вирощування одного циклу

\begin{tabular}{lcccc}
\hline \multicolumn{1}{c}{ Етапи вирощування } & 1 & 2 & 3 & 4 \\
\hline Кількість риби на початку етапу (екз.) & 30000 & 24000 & 20400 & 17748 \\
Вага (г) & $1,50-20$ & $20-100$ & $100-300$ & $300-1000$ \\
\hline
\end{tabular}

Для порівняння: нині у господарстві практикують вирощування риби за два цикли кожен тривалістю 6 місяців. У першому та другому циклах одержують по 26200 кг товарного сома, що за рік становитиме: $26200 \times 2=52400$ кг.

Кожен цикл також складається із чотирьох етапів, які проходять за хаотичного розподілу риби у різних ємкостях, коли проводять сортування риби. (рис. 2).
Для поліциклічного методу за допомогою процеcopa Excel (табл. 2) встановили потребу господарства у мальках кларієвого сома, а саме: 30000 екз.

Враховуючи те, що на кожному етапі виживає певний відсоток риби, розрахуємо ії кількість та загальну масу. Результати узагальнено у табл. 4.

\section{Таблиця 4}

Кількість кларієвого сома на різних етапах вирощування одного циклу

\begin{tabular}{lccc}
\hline Етапи вирощування риби & $\begin{array}{c}\text { Маса риби наприкінці кожного } \\
\text { етапу вирощування (г) }\end{array}$ & $\begin{array}{c}\text { Кількість кларієвого } \\
\text { сома (екз.) }\end{array}$ & $\begin{array}{c}\text { Загальна маса вирощеної } \\
\text { риби (кг) }\end{array}$ \\
\hline 1 етап & 20 & 24000 & 480 \\
2 етап & 100 & 20400 & 2040 \\
3 етап & 300 & 17748 & 5324 \\
4 етап & 1000 & 15973 & 15973 \\
\hline
\end{tabular}

Кількість корму, яка необхідна для годівлі кларієвого сома протягом різних етапів його вирощування, розрахували за формулою 1 :

для мальків на першому етапі:

$24000 \times 1,1 \times(20-1,5)=488400(г), 488$ кг;

для риби на другому етапі вирощування:

$20400 \times 1,0 \times(100-20)=1632000$ (г) 1632 кг;

на третьому етапі вирощування:

$17748 \times 1,0 \times(300-100)=3549600$ (г) 3549,6 кг;

на четвертому етапі вирощування:

$15973 \times 1,0 \times(1000-300)=11181240$ (г) 11181,2 кг.

Таким чином, для годівлі малька необхідно згодувати 488,40 кг корму “Біомар" (закупівельна ціна 60 грн за 1 кг корму). Для годівлі кларієвого сома на інших етапах вирощування використовують корм українського виробництва м. Золотоноша (закупівельна ціна 22 грн за 1 кг корму) у кількості:

$1632+3549,6+11181,2=16362840$ кг $(16362,84$ тонн $)$.

Робити висновок про виробничу діяльність рибницького господарства можна лише за економічними показниками. Серед показників, які визначають економічну ефективність виробництва, найважливішими вважаються собівартість одиниці продукції, валовий прибуток та рівень рентабельності.

Обчислення загальних витрат на вирощування товарної риби і валового прибутку від реалізації товарної продукції дає змогу визначити величину валового прибутку.

Рівень рентабельності виробництва визначається шляхом ділення валового прибутку на загальні витрати на вирощування товарної продукції (собівартість реалізованої продукції) та виражається у відсотках.

Всі витрати на виробництво товарної продукції поділяються на прямі та непрямі. До перших належать витрати, безпосередньо пов'язані з вирощуванням товарної риби, а саме: вартість рибопосадкового матеріалу, кормів, заробітна плата робітників. До непрямих виробничих витрат зараховують: витрати на амортизацію обладнання, ремонтні роботи, транспортні послуги, паливо, електроенергію, адміністративні витрати тощо.

Для визначення основних економічних показників, які відображають господарську діяльність рибоводного підприємства, проведемо такі розрахунки.

Визначаємо вартість реалізованої товарної продукції. За рік господарство отримує 15973 кг $\times 8=127784$ кг кларієвого сома, якого реалізує за ціною 70 грн за 1 кг, тому вартість реалізованої товарної продукції становитиме:

127784 кг $\times 70,00$ грн/кг $=8944880$ грн.

Розрахуємо прямі витрати на вирощування товарного кларієвого сома.

Щоб розрахувати виробничі витрати на зарибок, необхідно знати потребу господарства у мальку. За вартості 1 малька сома 1,00 грн витрати на придбання зарибку на 8 циклів вирощування становитимуть:

$(30000$ екз. $\times 8) \times 1,00$ грн $=240000$ грн;

Визначаємо вартість кормів. Вона становитиме: корм для годівлі малька:

$(488,4$ кг $\times 8) \times 60,00$ грн $/ \kappa г=234432$ грн;

корм для годівлі риби на інших етапах вирощування:

$(287232$ кг $+624729,6 \kappa \Gamma+1967898$ кг $) \times$ 22,00 грн/кг $=2879860$ грн.

Загальні витрати на корм: 234432 грн +2879860 грн $=3114292$ грн.

Для обслуговування УЗВ, де вирощуватиметься кларієвий сом, буде потрібно 5 рибоводів. Якщо роботи на басейнах будуть тривати близько 12 місяців у році, тоді за рік вирощування риби потрібна буде така кількість ставок:

$$
5 \text { чол. } \times 12 \text { міс. } \times 1 \text { рік }=60 \text { ставок. }
$$


За середньої заробітної плати одного працівника 8000,00 грн - фонд заробітної плати становитиме:

$$
60 \times 8000 \text { грн }=480000 \text { грн. }
$$

Таким чином, прямі витрати на вирощування риби становитимуть:

$$
240000+3114292+480000=3834292 \text { грн. }
$$

Непрямі виробничі витрати на даному господарстві становлять 30 \% від прямих витрат - 1150288 грн. Таким чином, загальні виробничі витрати становитимуть:

$$
3834292+1150288=4984580 \text { грн. }
$$

\section{Таблищя 5}

Економічна ефективність вирощування товарної риби
Собівартість 1 кг товарної риби становитиме: 4984580/127784 = 39,0 грн.

Розрахуємо валовий прибуток від реалізації товарної продукції (формула 2):

$$
8944880-4984580=3960300 \text { грн. }
$$

Розрахуємо рентабельність виробництва (формула 3): $(3960300 / 4984580) \times 100 \%=79,5 \%$

Результати розрахунків узагальнимо в таблиці 5 .

\begin{tabular}{lc}
\hline \multicolumn{1}{c}{ Показник } & Значення \\
\hline Вирощено товарної риби, всього, кг & 127784 \\
Реалізаційна ціна 1 кг товарної риби, грн & 70 \\
Вартість реалізованої товарної продукції, грн & 8944880 \\
Собівартість реалізованої продукції (загальні витрати на вирощування товарної риби), & 4984580 \\
грн & 39 \\
Собівартість 1 кг товарної риби, грн & 3960300 \\
Валовий прибуток від реалізації товарної продукції,грн & 79,5 \\
Рентабельності виробництва, \% &
\end{tabular}

Таким чином, господарство, яке практикує 2циклічне вирощування кларієвого сома і за рік реалізує 52,40 тонни товарної продукції, за умови переходу на 8-циклічне виробництво отримає 127,784 тонни товарної риби, тобто у 2,4 раза більше. Це означає, що раціональніше використовуються виробничі потужності та технологічне обладнання.

\section{Висновки}

1. Для оптимізації роботи господарства з вирощування товарного кларієвого сома в УЗВ застосування поліциклічного (8-циклічного) методу замість 2циклічного, який діє на теперішній час, дозволить раціональніше використовувати виробничі потужності та технологічне обладнання i реалізувати 127,784 тонни риби, що у 2,4 раза більше.

2. Для реалізації технології необхідно вирощувати таку кількість риби: на 1 етапі - 24000 екз., на 2 етапі - 20400 екз., на 3 етапі - 17748 екз., на 4 етапі - 15973 кожного 3 8-циклів. За рік господарство реалізує 127784 езк. кларієвого сома середньою масою 1 кг.

3. Витрати господарства на комбікорма становлять: на корм для мальків (“Біомар”) - 234432 грн, на корм для інших вікових груп кларієвого сома 2879860 грн. Загальні витрати на корм - 3114292 грн.

4. За дотримання всіх вимог 8-циклічного технологічного процесу вирощування кларієвого сома в УЗВ (загальний об'єм басейнів - 131 м $^{3}$ ) собівартість 1 кг риби становитиме 39 гривень, підприємство отримає 3960300 грн валового прибутку від реалізації товарної продукції, рентабельность виробництва становитиме 79,5\%.

Відомості про конфлікт інтересів. Автори стверджують про відсутність конфлікту інтересів щодо іхнього вкладу та результатів досліджень.

\section{References}

Grynevych, N. (2016). Features of bio filters with defferent types of filler plants in closed water acuaculture. Scientific Messenger LNUVMBT named after S.Z. Gzhytskyj, 18(3(70)), 57-61. doi: 10.15421/nvlvet7013.

Grynevych, N. (2017). The content of nitrifying microorganisms in the water of the biofilter reactor for closed water supply system during for the use of different types of filler. Scientific Messenger LNUVMB, 19(82), 184-187. URL: https://nvlvet.com.ua/index. php/journal/article/view/1362.

Hrebeniuk, T. V., \& Konstantynenko, H. V. (2015). Metody ochystky vody na rybovodnykh pidpryiemstvakh v umo-vakh vyroshchuvannia ryby $\mathrm{v}$ ustanovkakh zamknutoho vodopostachannia. Heoekolohiia ta okhorona pratsi, 28, 110-114. doi: 10.20535/20795688.2015.28.43048 (in Ukrainian).

Hrynevych, N. Ie. (2016). Osoblyvosti vykorystannia biofiltriv z riznymy typamy napovniuvacha $\mathrm{v}$ ustanov-kakh zamknutoho vodopostachannia. Naukovyi visnyk Lvivskoho natsionalnoho universytetu veterynar-noi medytsyny ta biotekhnolohii im. S.Z. Gzhytskoho, 18, 3(70), 57-61. doi: 10.15421/nvlvet7013 (in Ukrainian).

Hrynevych, N. Ie. (2017). Mikroorhanizmy protsesiv nitrohennoho tsyklu u vodi reaktora biofiltra $\mathrm{v}$ ustanovkakh zamknutoho vodopostachannia za vykorystannia riznykh napovniuvachiv. Naukovyi visnyk veterynarnoi medytsyny: zb. nauk. prats, 1(133), 131-136 (in Ukrainian).

Hrynevych, N. Ie., Khomiak, O. A., Prysiazhniuk, N. M., \& Mykhalskyi, O. R. (2019). Analiz hidrotekhnolohichnoi skladovoi industrialnykh akvaferm za zamknutoho vodopostachannia. Vodni bioresursy ta akvakultura, 2, 59-76. URL: http://rep.btsau.edu.ua/handle/ BNAU/3805 (in Ukrainian). 
Hrynevych, N., Prychepa, M., Kovalenko, Yu., Vodianitskyi, O., Svitelskyi, M., Fotin, O., Zahorui, L., Zharchynska, V., Gutyj, B., Kulish, S., Honcharenko, V., Velesyk, T., Sachuk, R., Stravsky, Ya., Boltyk, N. (2021). The role of macrophytes in waterfowl reproduction. Ukrainian Journal of Ecology, 11(2), 320 326. doi: 10.15421/2021 117.

Juin, S. K., Sarkar, S., Maitra, S., \& Nath, P. (2017). Effect of fish vitellogenin on the growth of juvenile catfish, Clarias gariepinus (Burchell, 1822). Aquaculture Reports, 7, 16-26. doi: 10.1016/j.aqrep.2017.05.001.

Oké, V., \& Goosen, N. J. (2019). The effect of stocking density on profitability of African catfish (Clarias gariepinus) culture in extensive pond systems. Aquaculture, 507, 385-392. doi: 10.1016/j.aquaculture. 2019.04.043.

Orisasona, O., Falaye A., et al. (2017). Effect of phytase supplementation on the growth, mineral composition and phosphorus digestibility of African Catfish (Clarias gariepinus) juveniles. Animal Research International, 14(2), 2741-2750. URL: https://www.ajol.info/index. php/ari/article/view/186900.

Prychepa, M., Hrynevych, N., Kovalenko, Yu., Vodianitskyi, O., Svitelskyi, M., Khomiak, O., Prysiazhniuk, N., Ishchuk, O., Sliusarenko, A., Kunovskii, J., Mihalskiy, O., Heiko, L., Trofymchuk, A., Gutyj, B., \& Levkivska, N. (2021). Diversity of aquatic animals in water bodies Opechen' (Dnipro floodplain, Ukraine). Ukrainian Journal of Ecology, 11 (3), 285-291. doi: $10.15421 / 2021173$.

Prychepa, M., Hrynevych, N., Martseniuk, V., Potrokhov, O., Vodianitskyi, O., Khomiak, O., Rud, O., Kytsokon, L., Sliusarenko, A., Dunaievska, O., Gutyj, B., Pukalo, P., Honcharenko, V., Yevtukh, L., Bozhyk, L., Prus, V., \& Makhorin, H. (2021). Rudd
(Scardinius Erythrophthalmus 1., 1758) as a bioindicator of anthropogenic pollution in freshwater bodies. Ukrainian Journal of Ecology, 11(2), 253-260. doi: 10.15421/2021_108.

Romanova, E. M., Romanov, V. V., Lyubomirova, V. N., Shadieva, L. A., \& Shlenkina, T. M. (2020). Increase in nonspecific resistance of catfish (Clarias gariepinus) in industrial aquaculture. BIO Web of Conferences, 17, 00122. doi: 10.1051/bioconf/20201700122.

Stas, M. M. (2015). Perspektyvy vykorystannia ustanovok zamknutoho vodopostachannia pry pidvyshchenni zhyttiediialnosti ryb dlia zaryblennia vodoskhovyshcha. Perspektyvy rozvytku suchasnoi nauky: materialy konferentsii. (7-8 travnia, 2015 roku). Kyiv, 87-89 (in Ukrainian).

Strauch, S. M., Wenzel, L. C., Bischoff, A., Dellwig, O., Klein, J., Schüch, A., Wasenitz, B., Palm, H. W. (2018). Commercial African Catfish (Clarias gariepinus) Recirculating Aquaculture Systems: Assessment of Element and Energy Pathways with Special Focus on the Phosphorus Cycle. Sustainability, 10(6), 1805. doi: 10.3390/su10061805.

Vlasov, V. A. (2012). Vosproizvodstvo i vyrashhivanie klarievogo soma (Clarias gariepinus) v ustanov-kah s zamknutym vodoobespecheniem (UZV). Rybovodstvo i rybnoe hozjajstvo, 7, 26-35. URL: http://aquacultura.org/upload/files/pdf/biblio/fish/Вла сов_2012a.pdf(in Russian).

Vlasov, V. A. (2013). Vyrashhivanie klarievogo soma (Clarias gariepinus Burchell) pri razlichnyh uslo-vijah soderzhanija i kormlenija. Sostojanie i perspektivy razvitija presnovodnoj akvakul'tury: Me-zhdunar. nauch.-prakt. konf. (5-6 fevralja, 2013 goda) Moskva, 141-150 (in Russian). 